an independent administration. It is difficult to judge any Eastern publication by Western standards : the printing and lay-out of the present journal are certainly not good. Despite their shortcomings, however, these publications are valuable, for it is through such organs that Indian engineers are kept in touch with local progress in industrial practice and, when they enter the industrial field, with scientific developments as well.

\section{Post-doctorate Fellowships in Canada}

Some forty post-doctorate fellowships will be awarded by the National Research Council, Canada, in 1949-50 for research in pure chemistry and physics. The fellowships will be tenable in the National Research Council laboratories at Ottawa and in the labgratories of the Atomic Energy Project at Chalk B. ver, Ontario. There will be about twenty awards In chemistry, fifteen in physies and about six in atomic energy research. Fellowships are tenable for a period of one year but may be renewed for a second year upon application. The stipend is 2,820 dollars per annum and is free of income tax. A grant-in-aid of expenses will be made to persons from outside Canada, and a similar grant may be made on the termination of the fellowship. There are no restrictions as to the nationality of the applicant in the case of the Ottawa laboratories; but appointments at Chalk River are restricted to British subjects. Applications should be received at the National Research Council, Ottawa, not later than March 1, 1949, for this year's awards.

\section{Swedish Society for Clay Research}

A SwEDIsh Society for Clay Research was constituted at a/neeting at Hŏganäs, Sweden, on November 4, when representatives of geology, mineralogy, chemisty, soil science, ceramic industries, geotechnology, etc., were present. The Society will keep in gontact with the International Committee for Clay Sfadies (Comité International pour l'Étude des Argiles) formed in London last August. The following have been appointed members of committee of the new Swedish Society: Dr. G. Assarsson, of the Geological Survey, Stockholm (chairman); Dr. L. Silfverberg, of the Royal Swedish Geotechnical Institute, Stockholm (honorary secretary); E. Forslind (Swedish Cement and Concrete Research Institute, Stockholm); Dr. Rolf Norin (Höganäs), and Dr. Lambert Wiklander (Institute for Pedology, Ultuna, Uppsala).

\section{Sheffield Library: Technical Bibliographies}

THe Sheffield City Libraries have prepared fiftyfour bibliogray hies on a range of subjects in the fields of chemical/and industrial engineering, metallurgy, and physjal chemistry, with particular emphasis on the steo and metallurgical industries in Sheffield. Since/the number of copies is limited, the City Libarian states they can be sent only to research wbrkers or responsible works executives, and all inquiries should be addressed to him at the Adminis. tration Department, Central Library, Sheffield, 1.

\section{British Rheologists' Club}

Ax the annual general meeting of the British Rhegl6gists' Club, held at the Institute of Physics on October 29, 1948, the following officers were elected for the ensuing year : President, Prof. N. F. Mott ; Hon. Secretary, Dr. E. W. J. Mardles ; Hon. Treasurer, Dr. V. G. W. Harrison; Hon. Auditor,
Mr. A. de Waele. The following were also elected to the Committee : Dr. A. H. Nissan; Dr.J.G. Oldroyd ; Dr. G. W. Scott-Blair (editor); Mr. M. W. Thring; Mr. A. G. Ward (chairman); and (co-opted to represent the North of England) Mr. W. A. Richardson.

\section{Education for Family Life}

"Education for Family Life" is to be the theme of the planning forum which the British Social Hygiene Council is arranging on January 26, at 6.15 p.m. at the Planning Centre, 28 King Street, Covent Garden, W.C.2. This meeting is the second in a new series of forums which are to be held at formightly intervals during the period JanuaryMarch under the auspices of a group of voluntary societies engaged in social work. Mrs. Eva Hubback, principal of Morley College and chairman of the Education Committee of the London County Council, will be in the chair, and those taking part in the forum will be Dr. Letitia Fairfield, Dr. Ethel Dukes and Mr. Geoffrey Martin. Time will be allowed for discussion. Further information and tickets (price 18.) can be obtained at the door, or from the Planning Centre, 28 King Street, Covent Garden, London, W.C.2.

\section{University of London}

THE following appointments in the University of London have been announced :

Dr. C. B. Allsopp, to the University readership in physics tonable at Guy's Hospital Medical School; Dr. C. K. Simpson, to the part-time University readership in forensic medicine tenable at Guy's Hospital Medical School.

The following have been appointed readers in respect of the posts now held by them : Dr. W. E. Duncanson, University College (physics); Dr. D. B. Fry, University College (experimental phonetics) Dr. O. H. K. Spate, London School of Economics (geography); Dr. Andrew Wilson, University College and University College Hospital Medical School (applied pharmacology).

\section{Announcements}

The Federal Council of the Australian Institute of Agricultral Science has awarded its Medal for 1949 to prof. W. L. Waterhouse, of the University of Sydney. The award is made for the most outstanding service to Australian agriculture during the preceding ten years.

THE former Institute of Physical and Chemical Research, Womagome, Tokyo, has been dissolved and the work taken over by the Scientific Research Instifute, Ltd., at the same address. Its publications, the Scientific Papers and the Bulletin of the Institute, have been renamed the Journal and the Reports of the Scientific Research Institute.

VouUME 30 of the Transactions of the British Mycologipa Society is a jubileo volume which places on permanent record the papers presented at the conmemorative meeting in London during October $20-25,1946$. These deal with the Society's history, and with various facets of modern mycology; a full review of their contents appeared earlier in Nature (158, 693; November 16, 1946).

Erratum. In "Regenerated Keratin Fibres" by Dr. R. Wormell and Dr. F. Happey in Nature of Janyeryy 1, p. 18, in the legend to the figure, last line, for $D=3 \mathrm{~cm}$. read $D=4 \mathrm{~cm}$. 